\title{
Application of Information Technology for the Expert System Shell of Egyptian Clover in the Old Lands
}

\author{
Bondok Abdel Aziz ${ }^{1}$, Maryam Hazman ${ }^{2}$
}

\begin{abstract}
This study was established an expert system technology of Egyptian Clover (ESTA) program contains two copies (language English and Arabic) in terms of computer programs designed to mimic the reasoning of human experts was established. These programs, are able to take into account the relative importance of different criteria to the user. These program are useful in varieties aginst biotic and abiotic stress. And expert system is able to search a computer database to select the varieties that appeared the best reflect this particular bias. The result of this search is a list of cultivars ranked as to how well they meet the user's request. It is designed to incorporate detailed information about Egyptian Clover production regarding site, soil, machinery, management levels and yield information to simulate the annual costs and returns over the Egyptian Clover stand life. ESTA requires information from several domains of expertise such as agronomy, entomology, agricultural engineering and agricultural economy.

ESTA is a form of artificial intelligence, may soon become an important management tool for agribusiness dealers, county agents, agricultural consultants and farmers. ESTA can make the specialized knowledge of an expert available to farmers when making critical management decisions. ESTA also can informs the user as to how the recommendation or conclusion was reached on the screen or on the print - out. ESTA modules procedures used by a forage expert in determining agro economic recommendations for successful establishment and production of Egyptian Clover. With ESTA information is readily available to Egyptian Clover producers for making management decisions relative to liming, fertilization, irrigation, drainage, weed control, longevity of stand, variety recommendations, method and rate of seeding.

This study describes a microcomputer program called ESTA which is an expert system for Egyptian Clover cultivar selection. ESTA is an expert system used as an educational tool for extension people and the Egyptian Clover growers.
\end{abstract}

Key words: Expert system technology, Egyptian Clover, artificial intelligence, management tool.

\footnotetext{
DOI: 10.21608/ASEJAIQJSAE.2020.135169

${ }^{1}$ Forage Crops Res. Dept., Field Crops Res., Inst. ARC., Giza, Egypt.

${ }^{2}$ Central Lab for Agricultural expert systems.

Received December 01, 2020, Accepted, December 27, 2020
}

\section{INTRODUCTION}

The impact of using expert system for agriculture is very useful in reducing cost and increasing yield. (Rafea et al,1995)

Expert system a form of artificial intelligence emerged as a new field nearly four decades ago. However progress was slow for several decades due to the early approach of utilizing sophisticated reasoning techniques without relying on a knowledge base. During the past decade, most of the artificial intelligence work shifted to knowledge - based expert systems. At present, the major limitation to the development of knowledge - based expert systems, especially in agriculture, is the lack of well - trained knowledge engineers (Giarratano and Riely, 1989).

An expert system is a written program, usually computerized, that imitates the decision - making process of a human expert. Expert systems offer many advantages to modern day, high technology in agriculture. some of these advantages are:

- Permits mass production of expertise resulting in increased availability to agricultural producers.

- Very fast response when expertise is needed.

- Expertise is permanent - no illness, retirement, or death.

- Is easily modified and / or updated.

- User can observe the reasoning involved in reaching a conclusion.

- Development of C language integrated production system (CLIPS) will result in greatly reduced cost of expertise to user.

Egyptian Clover management requires many expert domain such as entomology, agronomy, agricultural economics, plant pathology and animal science. In addition, successful production of Egyptian Clover requires significant management time and more capital investment than other crops (Limsupavanich. et al., 1994).

To increase the competitiveness and production of Egyptian Clover, this study developed a series of expert system called the Egyptian Clover integrated management system to incorporate knowledge from 
several areas of expertise and to deliver the instantaneous consultations and recommendation in Egyptian Clover production (Refea et al., 1993).

The expert system was originally developed for selecting Egyptian Clover varieties and has been greatly expanded and updated to provide expertise for Egyptian Clover establishment and production management decisions (Rhykerd et al., 1988, 1989).

With the rapid proliferation of information on Egyptian Clover cultivars, forage specialists have found an increasingly difficult to match desired criteria with specific cultivars using printed publications. One solution to this difficult is to transfer the printed information into an electronic form which could be more easily and rapidly accessed and a queried by a personal computer (Refea et al., 1994).

The objective of this study was to develop an Egyptian Clover management expert system which would make the expertise of a forage expert readily available to agricultural advisors and farmers when critical management decisions must be made.

\section{MATERIALS AND METHODS}

Egyptian Clover integrated management expert system consists of four units. WEED plus, Alfweev, HayMachs and ProfAIf as displayed in Fig. (1). The main objective is to develop a system to enhance the competitiveness and profitability of Egyptian Clover production in Egypt. Each unit of expert system is a standalone system. Weed plus is the Egyptian Clover weed management expert system containing knowledge of Egypt weeds. (Mitrpanont et al., 1993).

Management for Egyptian Clover growers provides recommendations for both preplanned and established stands and the cost- benfiton weed management, Alfaweed is the Egyptian Clover weedvil insect management expert system designed to provide recommendations on insect management cost and practice (SABELLA et al., 1989). Haymachs is a hay harvesting and machinery expert system providing a cost analysis of specific hay harvesting operation (cutting, taking and baling), finally Profalf is the last expert system developed to provide recommendations of Egyptian Clover economics and management practices (Limsupavanich, et al., 1992).

\section{Profal structure and development:}

Profalf is a user friendly expert system developed in a haybrid-structure of shell based, hypertext (Conklin, 1987) and conventional subprogram system (Dolushitz et al., 1988) Profalf is implemented in the knowledge pro-environment that provides both the expert system shell and hypertext system profalf manipulates the facts and the knowledge base via the expert system shell and provides explanations, recommendations and results via the hypertext system. In addition, it utilizes the complex simulation modely by loading and running conventional programs written in $\mathrm{C}$ language. These $\mathrm{C}$ subprograms are hidden to the user, profalf provides an easy to use menu system for program inputsud stores it as parameter files. Then, $\mathrm{C}$ subprograms retrieve the data from the parameter files, perform the complex computations and generate the output into the result files.

Both the parameter files and output files act like a black board for knowledge pro and $\mathrm{C}$ subroutines to communicate and exchange the information during the execution of profalf.

To develop profalf, it can be use the decomposition method dividing this system into small subsystem as illustrated in Figure(2). We acquire and interpret knowledge from the experts for each subsystem. Once the knowledge in each domain has been established, then all the experts define the interactions of the subsystems. The knowledge engineer selects the software development tool and programming language to implement PROFALF.

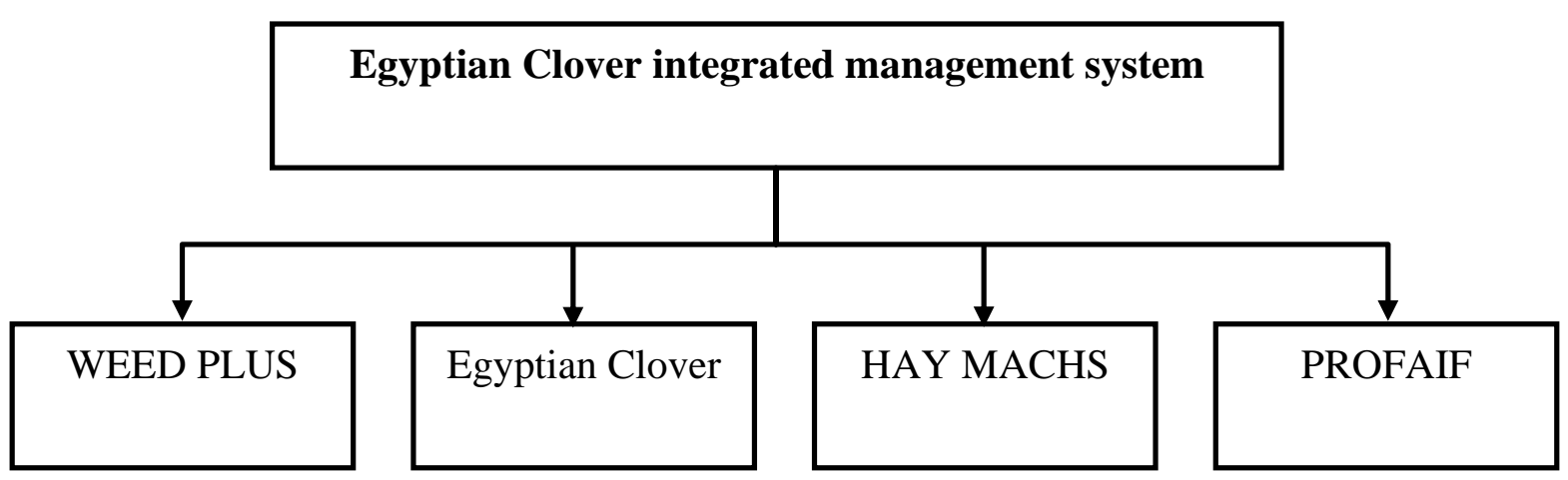

Fig. 1. Components of the expert system of Egyptian Clover 


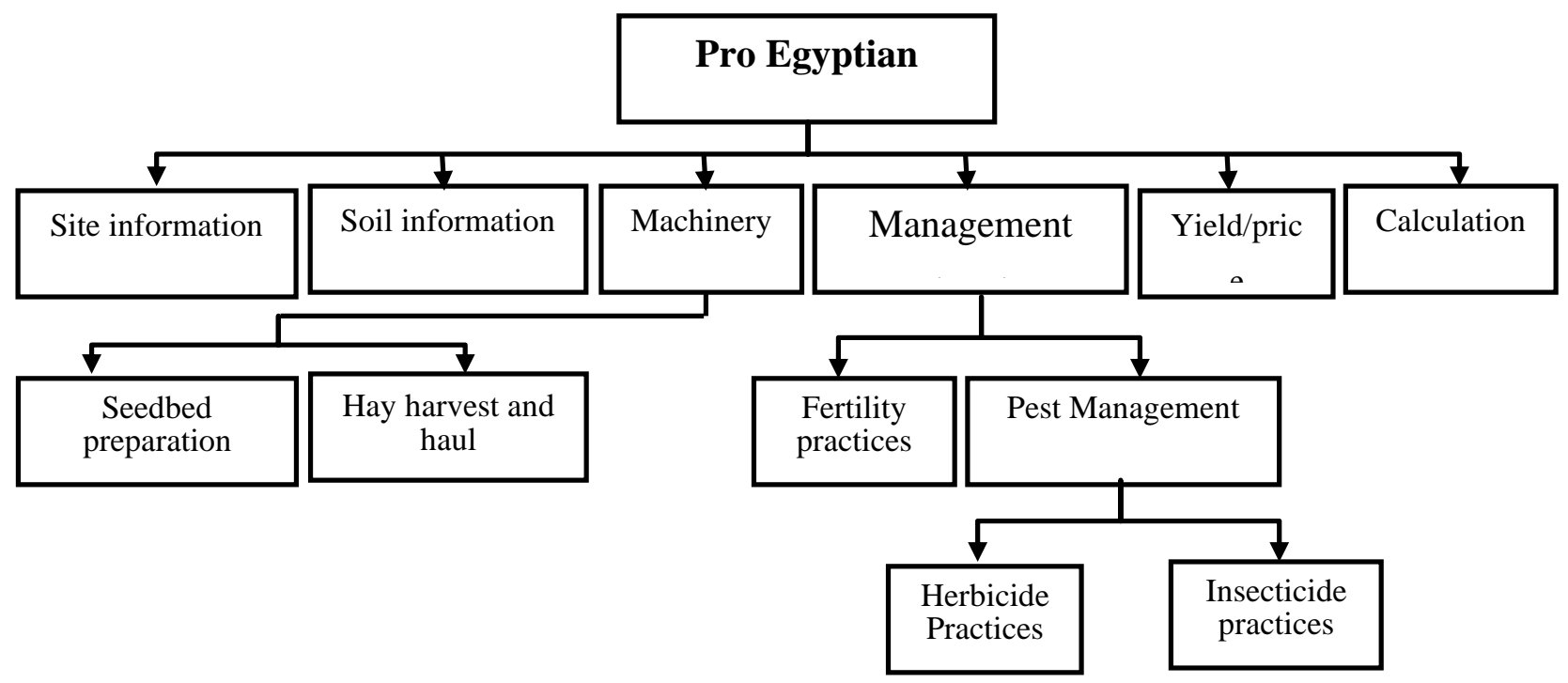

Fig. 2. Decompostion of Pro Egyptian

Each subsystem of PROFALF is developed as a frame work where the parameters are passed between each framework. The framework with the most interactions is created first, because it is the most significant and complicated unit. The other frameworks are created one at a time, until all units have been completed. The final step is to integrate and verify all units. The verifications step is a critical and time consuming process, because we need the appropriate data set to test the system and obtain the comments from all the experts (Fig. 2).
The expert system shell consists of an inference engine that determines the information that must be obtained (and in what order) from the knowledge base and from the user (Salah, et a., 1992).

The first step in the knowledge engineering process is for the knowledge engineer to establish a dialogue with the domain expert and elicit the appropriate knowledge from the domain expert. The knowledge engineer must then code the knowledge explicitly into the knowledge base. (Fig. 3).

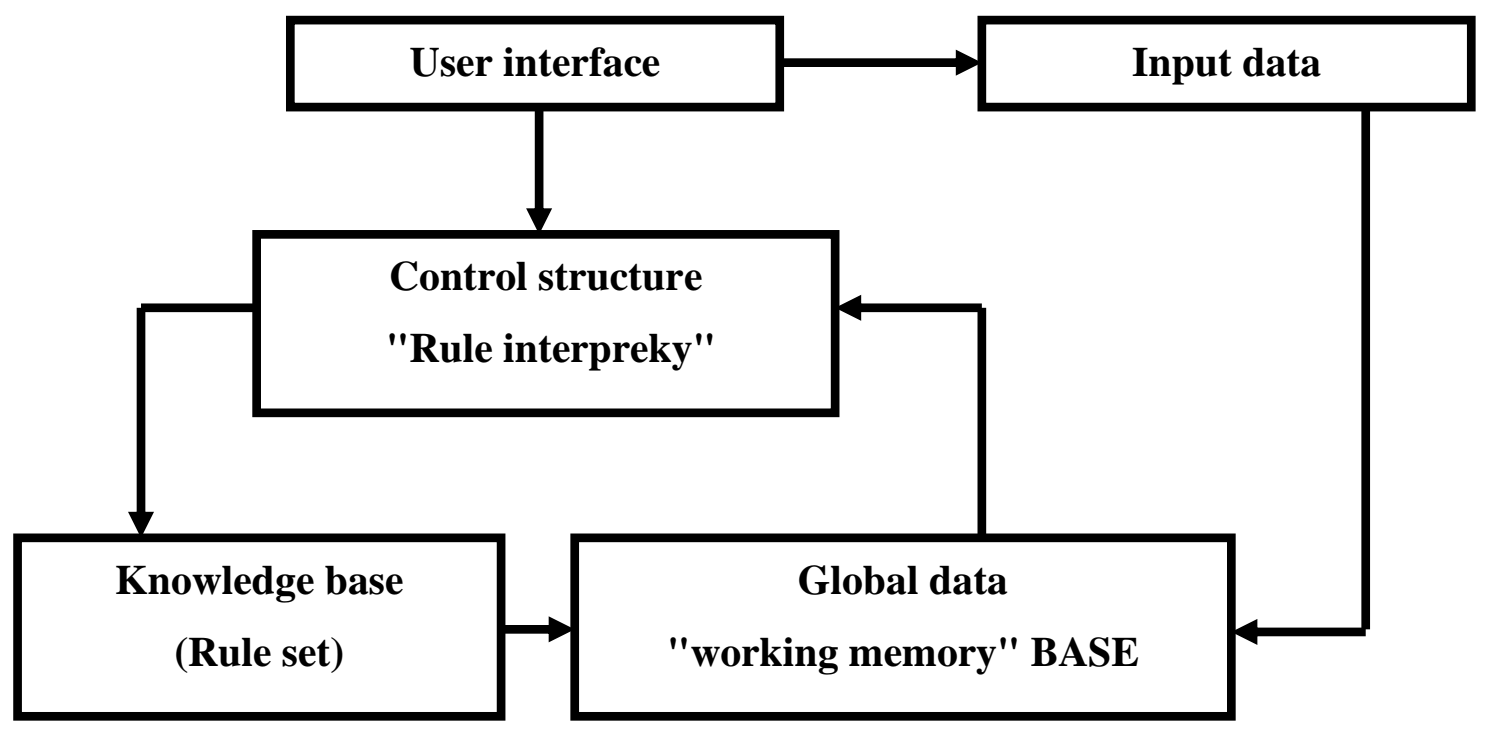

Fig. 3. Components of Expert System program of Egyptian Clover 
Expert system program of Egyptian Clover design the knowledge base of using the web knowledge acquisition tool (KAT) [M]. This tool was constructed by central lab for Agriculural expert systems (CLAES) using C\#. It facilitates the knowledge acquisition process and producing the expertise knowledge base. The Egyptian Clover Expertise knowledge was acquired and formalized in design from. Then the design was reviewed by domain experts before enter using the knowledge acquisition tool. The KAT enables us to produce the knowledge based using English and Arabic language (Schupthess, 1996).

The process of building knowledge - base expert system is referred to as knowledge engineering. This process requires a domain expert, a knowledge engineer, and a development tool (expert system shell).

The development tool was PC plus, expert system shell from Texas instruments, Inc. The expert system shell consists of an inference engine that determines the information that must be obtained (and in what order) from the knowledge base and from the user.

The first step in the knowledge engineering process is for the knowledge engineer to establish a dialogue with the domain expert and elicial the appropriate knowledge from the domain expert. The knowledge engineer must then code the knowledge explicitly into the knowledge base. The knowledge - based expert system is then evaluated by the domain expert. Any necessary modifications are given to the knowledge engineer for further refinement until the domain expert is satisfied with the performance of the expert system (Edward, 1993).

The knowledge base for Egyptian Clover management expert was developed but could easily be modified for other regions. Egyptian Clover management considerations and the sequence in which they were built into the knowledge base are as follows:

- Soil drainage: The first question posed to the user concerns the soil drainage classification, since this determines whether Egyptian Clover can be successfully grown and whether a phytophthora resistant variety will be required (Rhykerd et al., 1989).

- Soil pH: Egyptian Clover is sensitive to soil pH. Therefore, the user is asked if the soil $\mathrm{pH}$ is 6.6 or above. The recommendation given is based on the response to the soil $\mathrm{pH}$ level of the field to be seeded with Egyptian Clover (Rhykerd et al., 1989).

- Soil P test: This recommendation is based on soil p Level supplied by user.
- Soil K test: This recommendation is based on soil K level supplied by user (Rhykerd et al., 1989).

- Use of Egyptian Clover crop: Soil improvement only or as a forage (hy or silage) (Rhykerd et al., 1989).

- Weed control: Choice of companion crop or herbicides for weed control during establishment (Rhykerd et al., 1989).

- Expected longevity of stand: An indirect method of determining whether anthracnose resistant variety is required. Bacterial wilt resistance is also a consideration(Rhykerd et al., 1989).

- Variety recommendation: A list of varieties is presented which possess the necessary attributes to assure success in establishment and production as desired by the user. Varieties can be listed by Agricultural Research Center (ARC), if desired. The knowledge a base can be easily modified as varieties are released or discontinued (Rhykerd et al., 1989).

- Method and rate of seeding: Determined by input of user relative to seedbed preparation and method of seeding (Rhykerd et al., 1989).

The knowledge - based were obtained from the Forage Crops Research Department (ARC). This Egyptian Clover management system performance well provides recommendations that are satisfactory to the domain expert. However, this expert system will not be made available to potential users in its present form due to high cost and legal restrictions. Consequently, the next step is to convert this Egyptian Clover management expert system to ESTA. ESTA was just recently developed by the artificial intelligence section at Central Lab for Agricultural Expert Systems The ESTA experts system tool was designed to greatly reduce the cost and legal restrictions associated with the development and use of expert systems.

\section{RESULTS AND DISCUSSION}

The expert system ESTA included two subsystem the strategic subsystem and the tactical subsystem. The strategic subsystem consists of 7 modules namely: variety selection, pre-cultivation pest control, tillage, planting, irrigation, fertilization and harvest (Model 1).

The main function of the variety selection modules is to identify the appropriate variety for a specific field based on various parameters such as the soil types, the weather resistance to certain disease and others. The main function of the pre-cultivation pest control module is to generate recommendation of the preventive operations that should be done before cultivation based on the previous crop and other field specific historical data. The function of the tillage module is to select the appropriate machinery for tiling and parameters. 


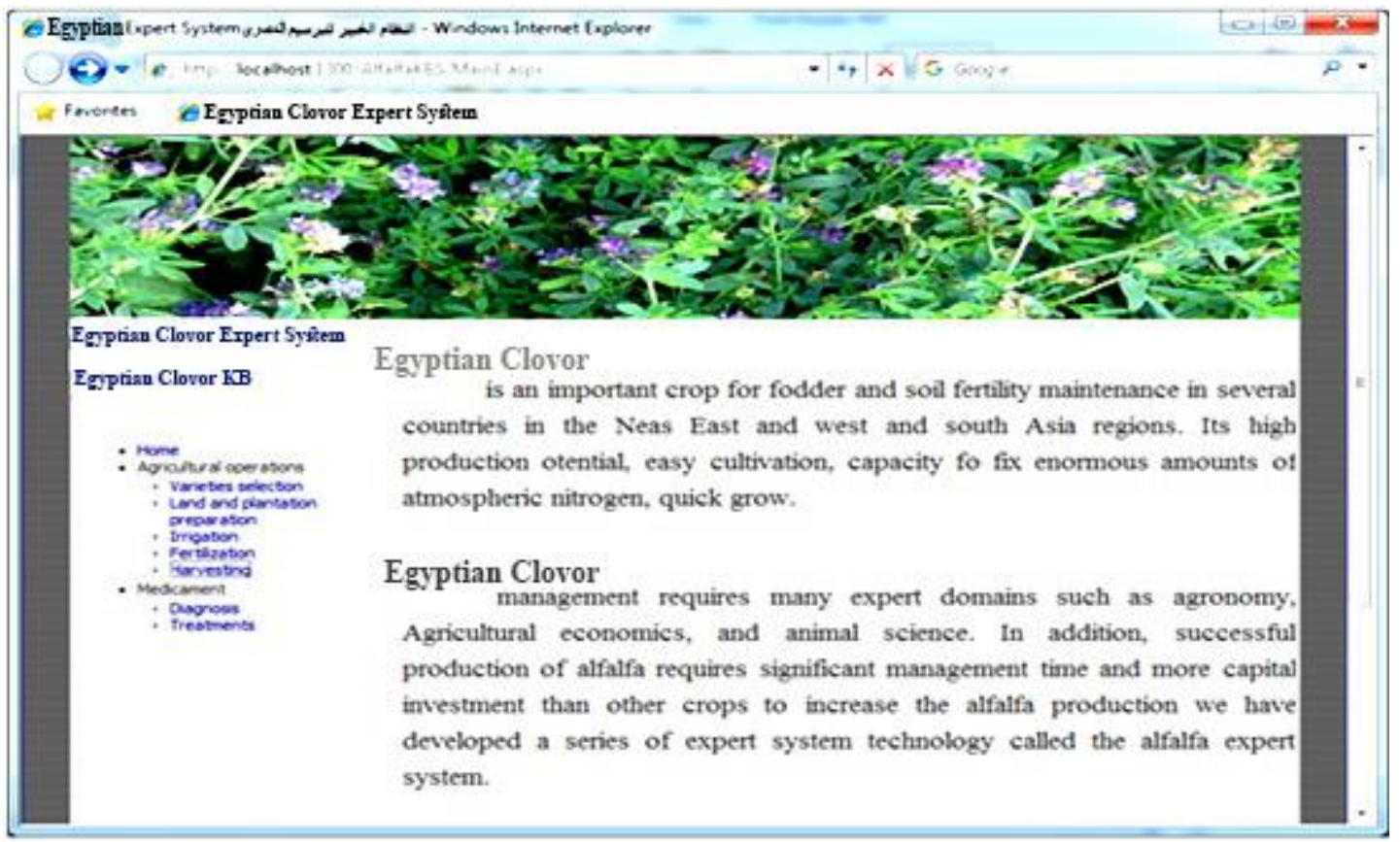

Module 1. Introduction and seve modules of expert system technology of Egyptian Clover

The function of the planting module is to decide on the planting date, distance between plants and method of planting, irrigation and fertilization which were similar to what has been described earlier. The only difference is that they are using the ESTA system to calculate the water quantity and nitrogen quantity. The functions of the harvest module is to generate recommendation concerning the harvest date, harvest machinery and storing the seeds (Similar Results were Observed by Kamel et al., 1995).

The tactical subsystem consists of two modules, namely weed identification and control, diagnosis and treatment. The weed identifications and control module is a picture based system such that the user can use them. The system provides advice to control this weed. The diagnosis and treatment module is similar to the corresponding module in the other systems.

The system ESTA is a menu- based program designed to minimize the time required to learn how to use it. System operation of expert systems of Egyptian Clover. Since the end user is a famer and his natural language is arabic, the Egyptian Clover expert system is started using Arabic. A user can run the english version by click on "Egyptian Clover Expert System" in the right menu. The primary application of the program is to obtain a list of cultivars that closely match characteristics desired by the user. A secondary application is to inform the user about various factors affecting Egyptian Clover cultivar selection. These two applications will be discussed in more detail by describing a typical session with ESTA. The main menu of ESTA offers the user five choices "system" "Edit" "configuration" "Info" and "Quit". By selecting the "system" option, the user is presented with another menu which includes the option to "Make Recommendation", fter selecting this option the program conducts an interview with the user. The first request in the default configuration is "select the site and soil information. Choices include: area agriculture, soil salinity and soil drainage. The next in query is "select the level of resistance required in your area for bacterial wilt (Simpliar results were obtained by Hannaway et al., 1985).

The final inquiry is for the level of resistance to vericillium wilt. After this query is answered ESTA searches through the cultivars in the database (which can be configured to include only certified varieties if desired) to determine how well they match the interview question responses. The best cultivars are then ranked and displayed according to how well they match the criteria supplied. Information on any one of these ranked cultivars is available by selecting that cultivars from the menu.

The database on Egyptian Clover cultivars includes site, soil and pest resistance information (insects, diseases and nematodes).

A subset database contains only cultivars approved by the ARC. To obtain information about factors that 
are important to selecting an appropriate cultivar, the user would select the "info" option from the main menu. This reveals another menu which offers the user to choice about ESTA use of certified seed "diseases" "fertility", irrigation, cutting and insects" selecting one of these options provides access to a system of text and color pictures that are electronically cross referenced through common key words. This type of information system, in which related topics are linked through common key words, is known hypertext system (Simpliar results were obtained by Hannaway et al., 1984).

It provides rapid way to move back and forth from one related topic to another. Key words pertaining to important Egyptian Clover pests are linked to color pictures that illustrate the visual symptoms of the problem. After selecting the system option, in the ESTA program select the pest resistance was grouped into five categories corresponding to highly resistant $(>50 \%)$, resistant (31-50\%), moderately resistant (15-30\%), low resistance (6-14\%) and susceptible (0-5\%) (Certified Egyptian Clover Seed Council, 1990).

User can select the suitable inputs his/her situation. These inputs values are nominated from the farmers' usual used words.

Cultivar status was denoted as certified, discontinued, experimental or blend. Cultivars listed as certified were those certified by the certified Egyptian Clover seed (Module 2).

For variety selection, a farmer select its region, soil type and salinity then the system provides him/her by the suitable varieties.

The expert system provides its usuer by the needed operation for land and plantation preparation according to seasons, available tools and soil type. For each operation, its detail will be displayed (Module 3).

Also, the expert system provides its users by the needed irrigation water and fertilization (Modules 4, 5).

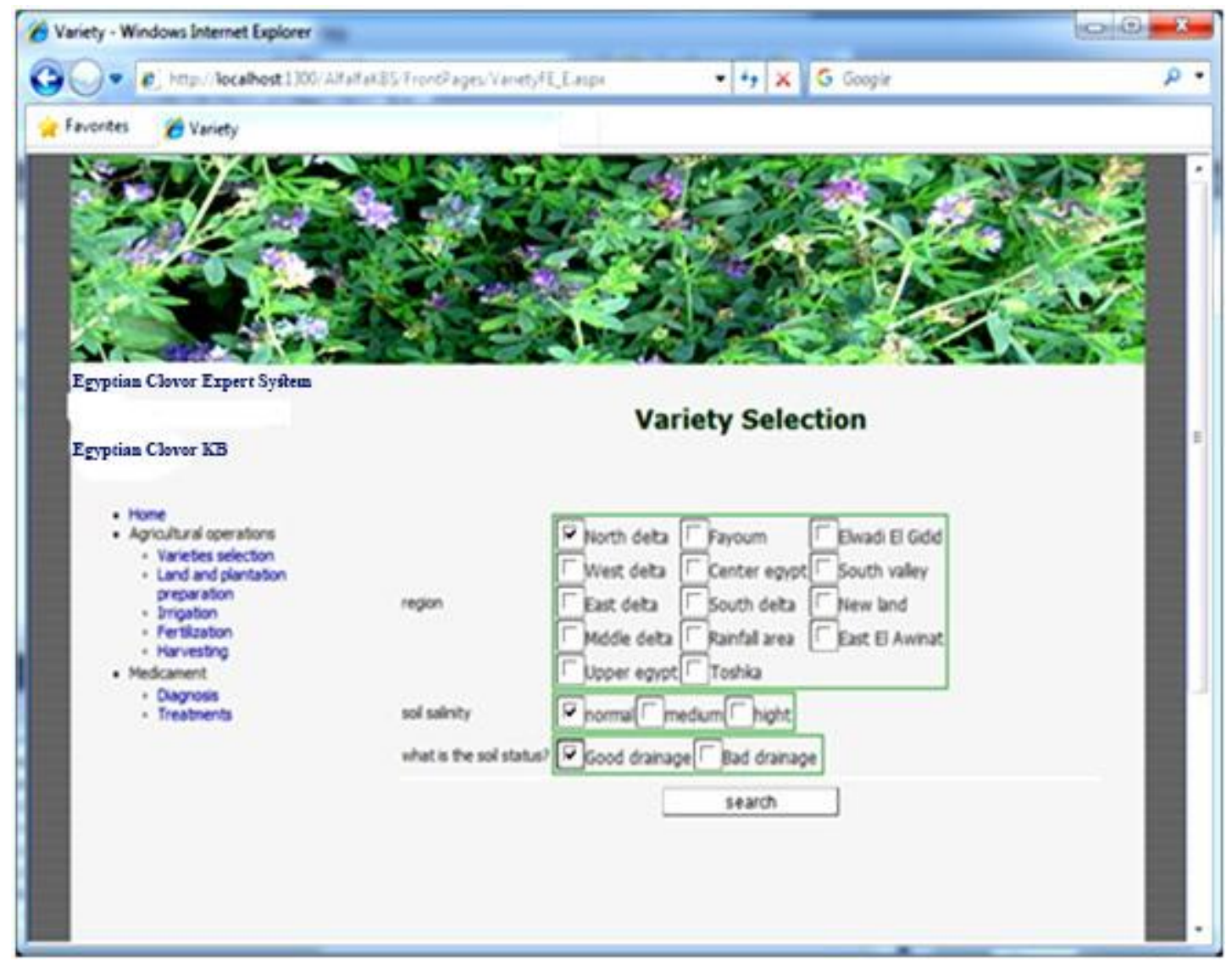

Module 2. Varieties slection from expert system technology of Egyptian Clover (ESTA) 


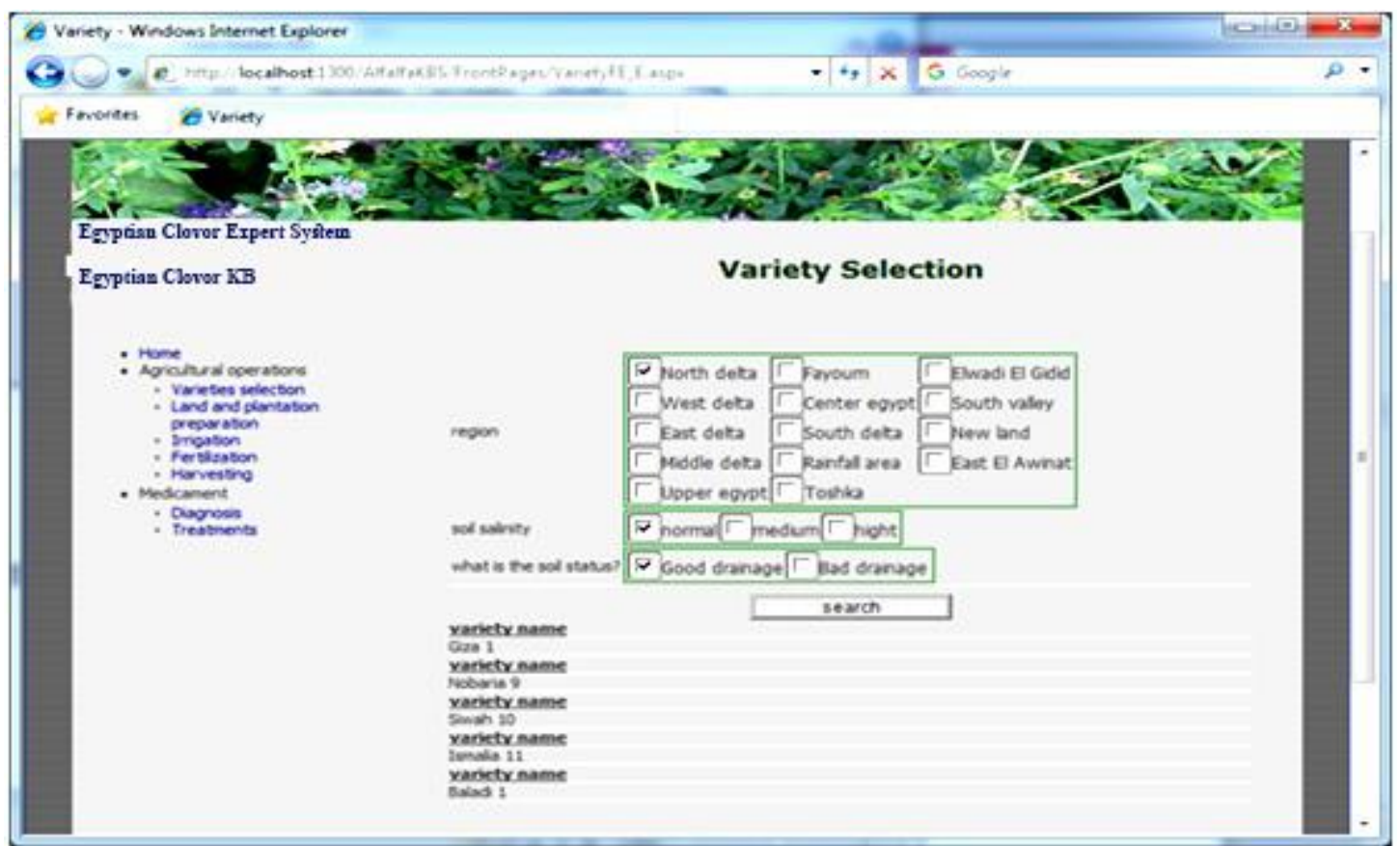

Module 2. Continued

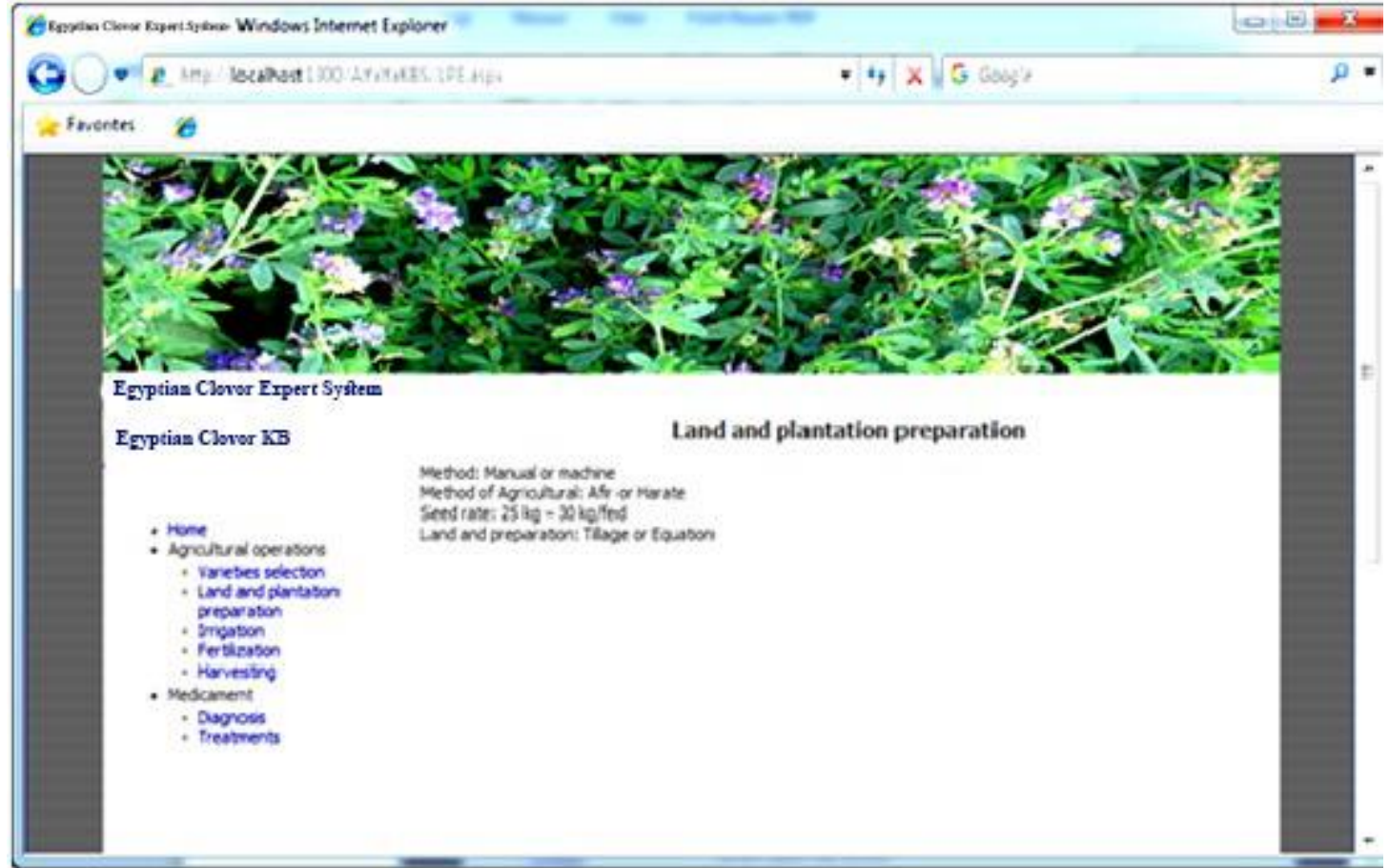

Module 3. Operation of land and plantation preparation from expert system technology of Egyptian Clover 


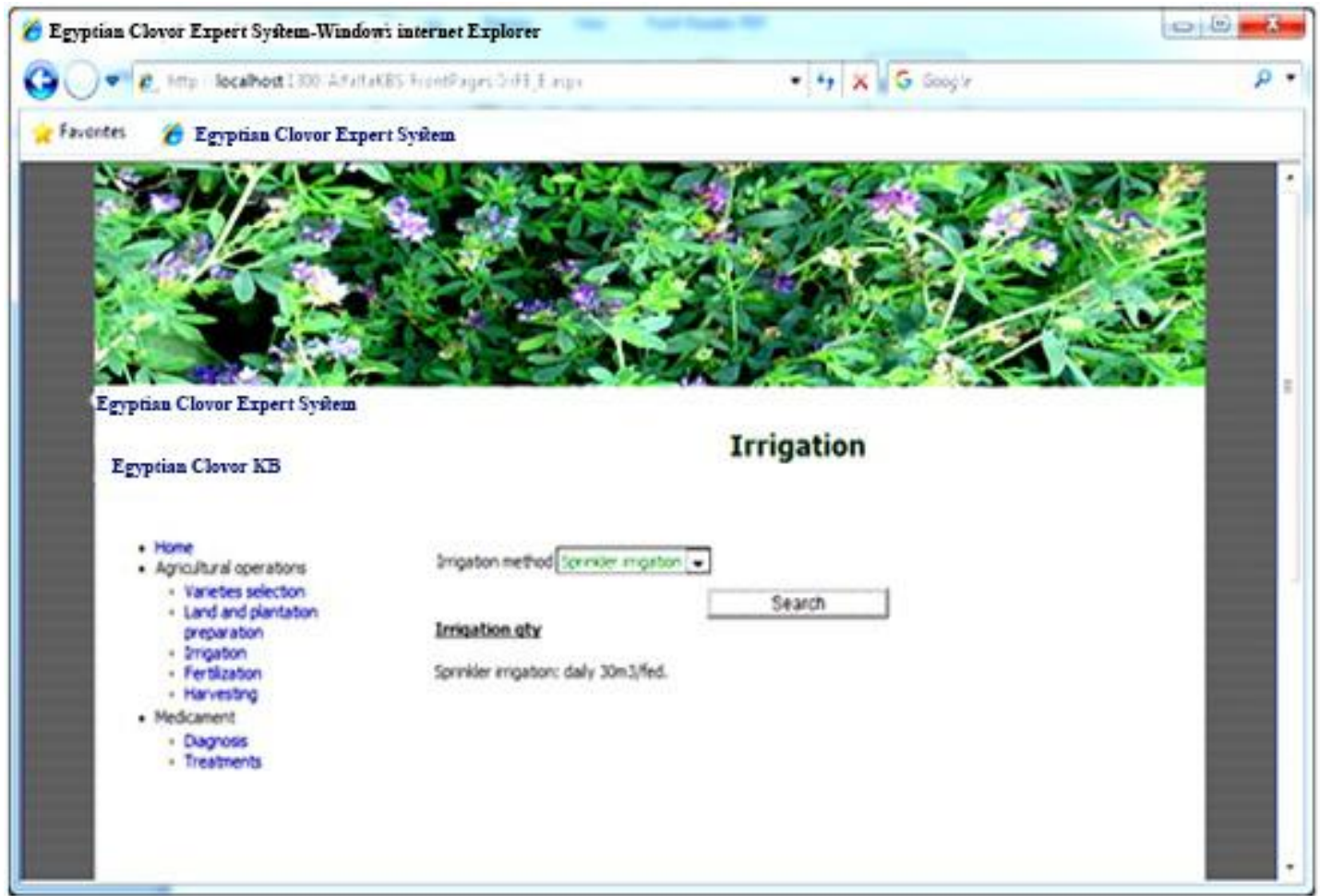

Module 4. Irrigation water databse from expert system eechnology of Egyptian Clover

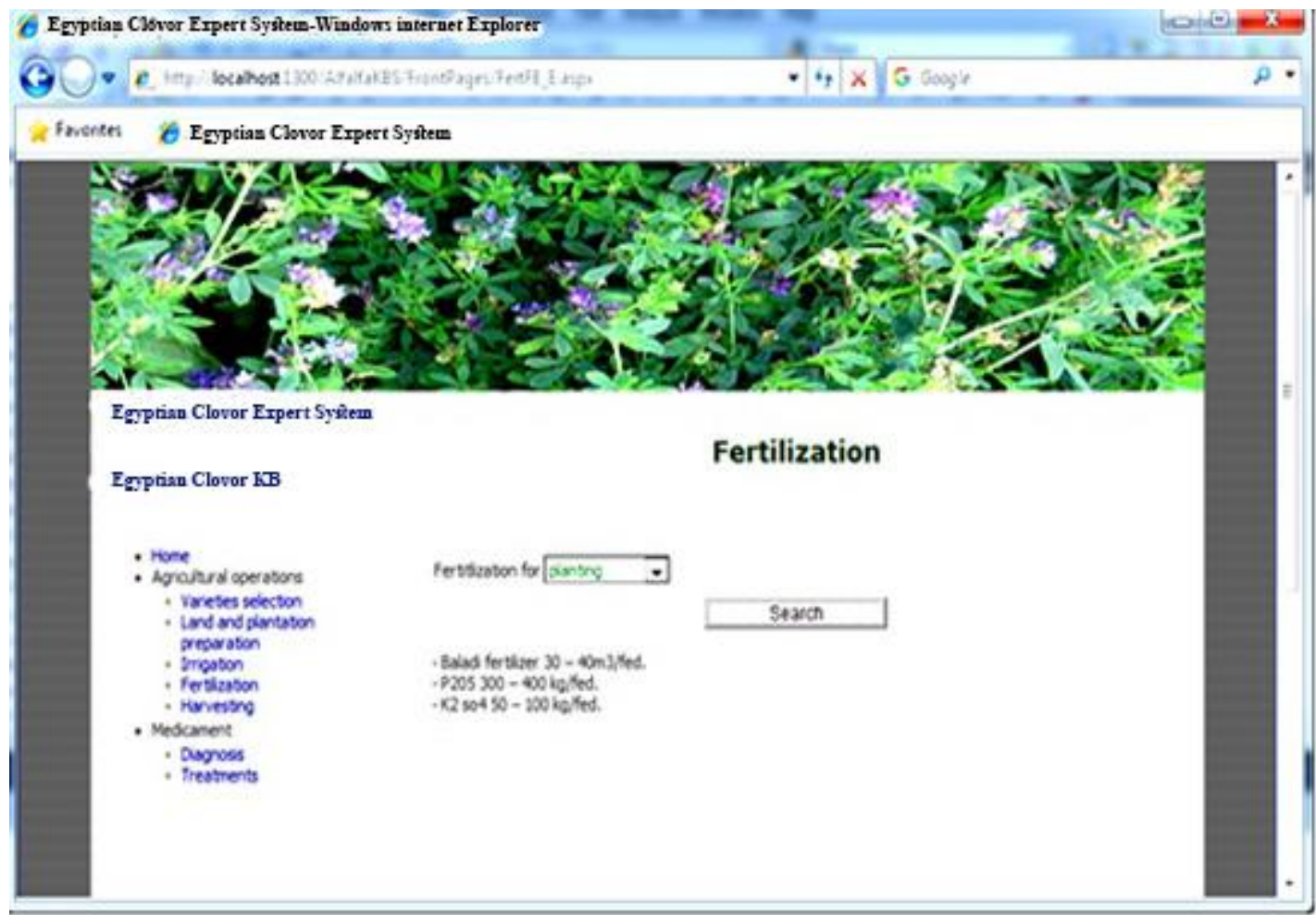

Module 5. Fertilization rates knowledge from expert system technology of Egyptian Clover 
For harvesting, the system provides the user a suitable way to do it (Module 6).

If the farm is infected by disorders, the user will use the diagnosis subsystem. The user could select the symptoms that appears in the farm. Then the infected disorder(s) will display, from treatment subsystem, the user will find how to treat the infected plants (Modules $7,8)$.

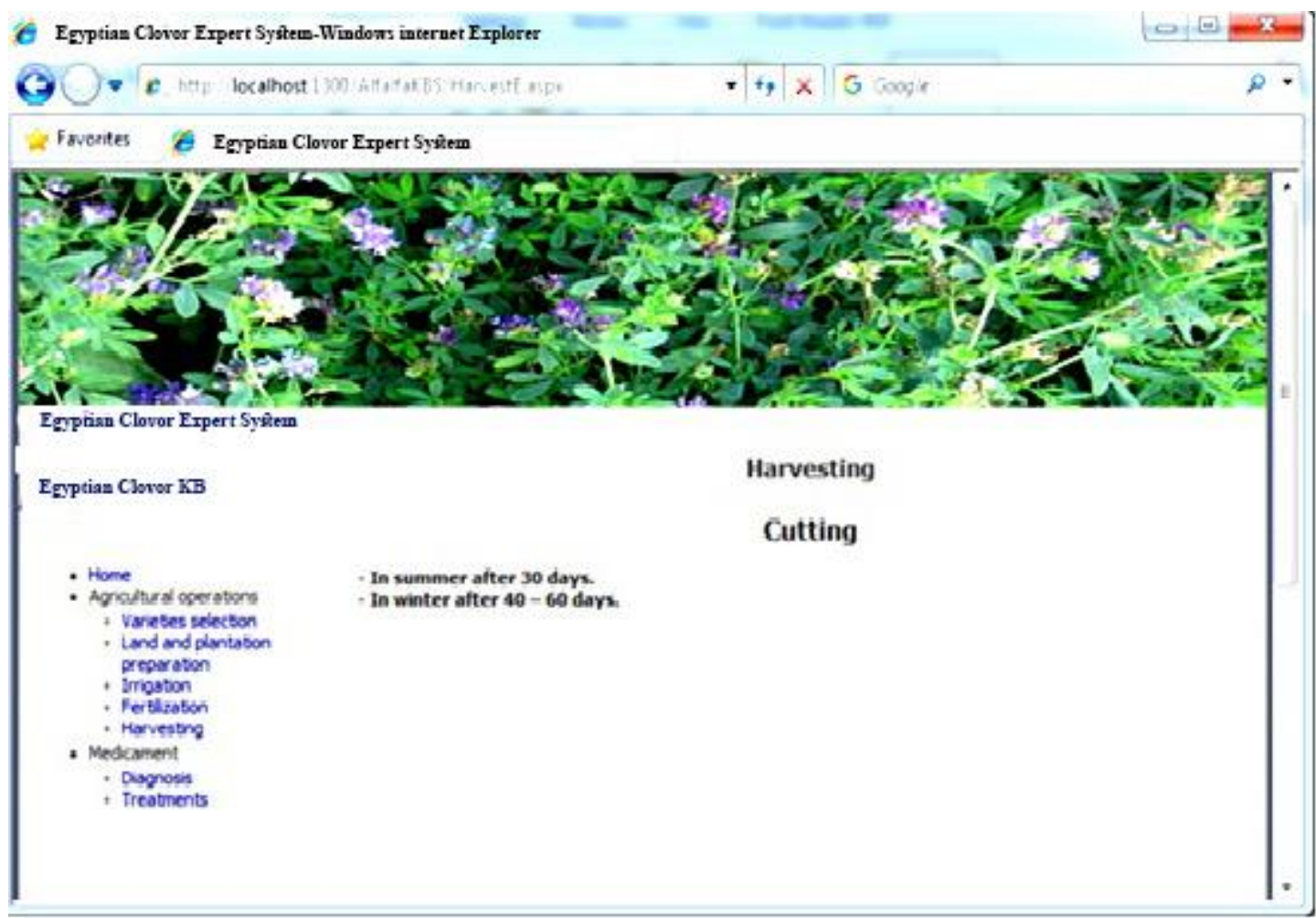

Module 6. Harvesting knowledge from expert system technology of Egyptian Clover

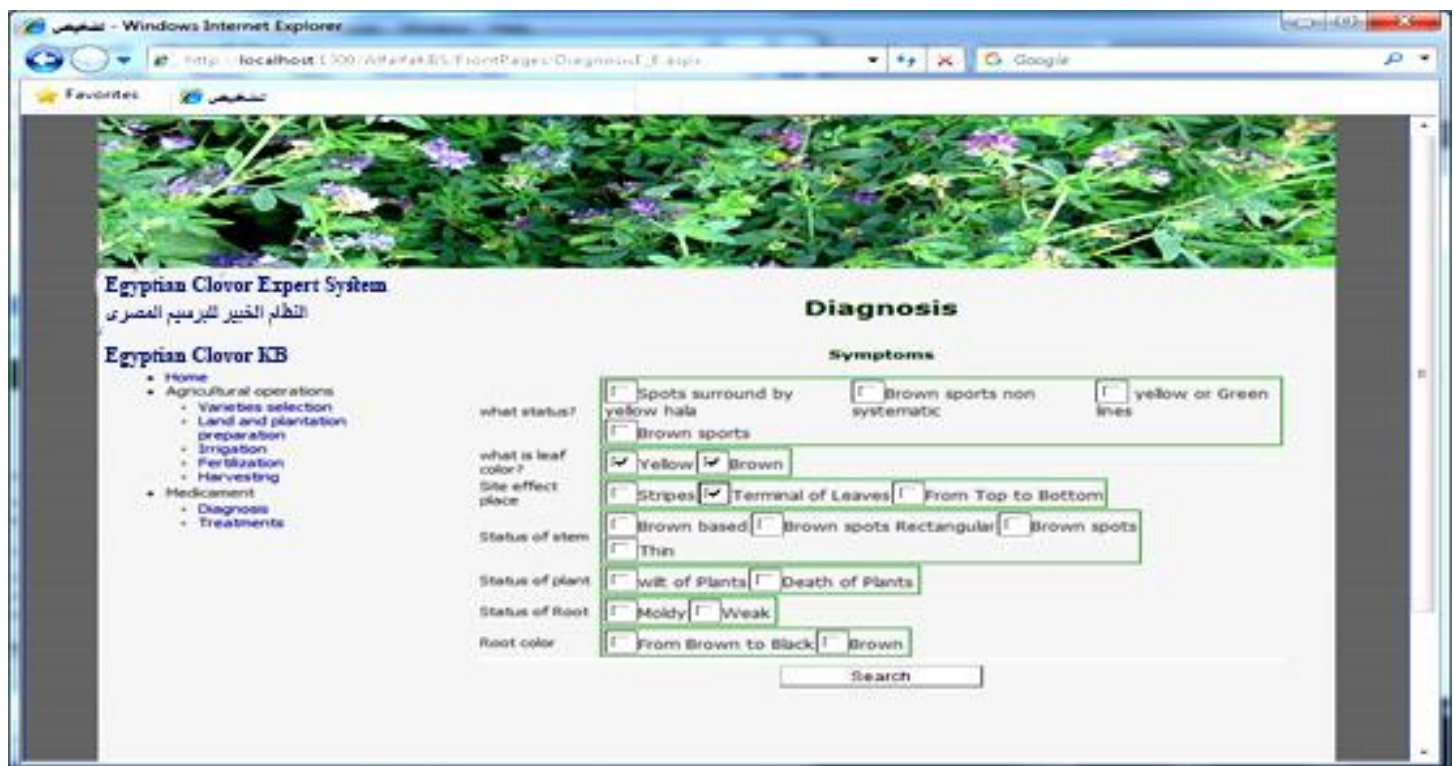

Module 7. Diagnosis and medicament subsystem of expert system technology of Egyptian Clover (ESTA) 


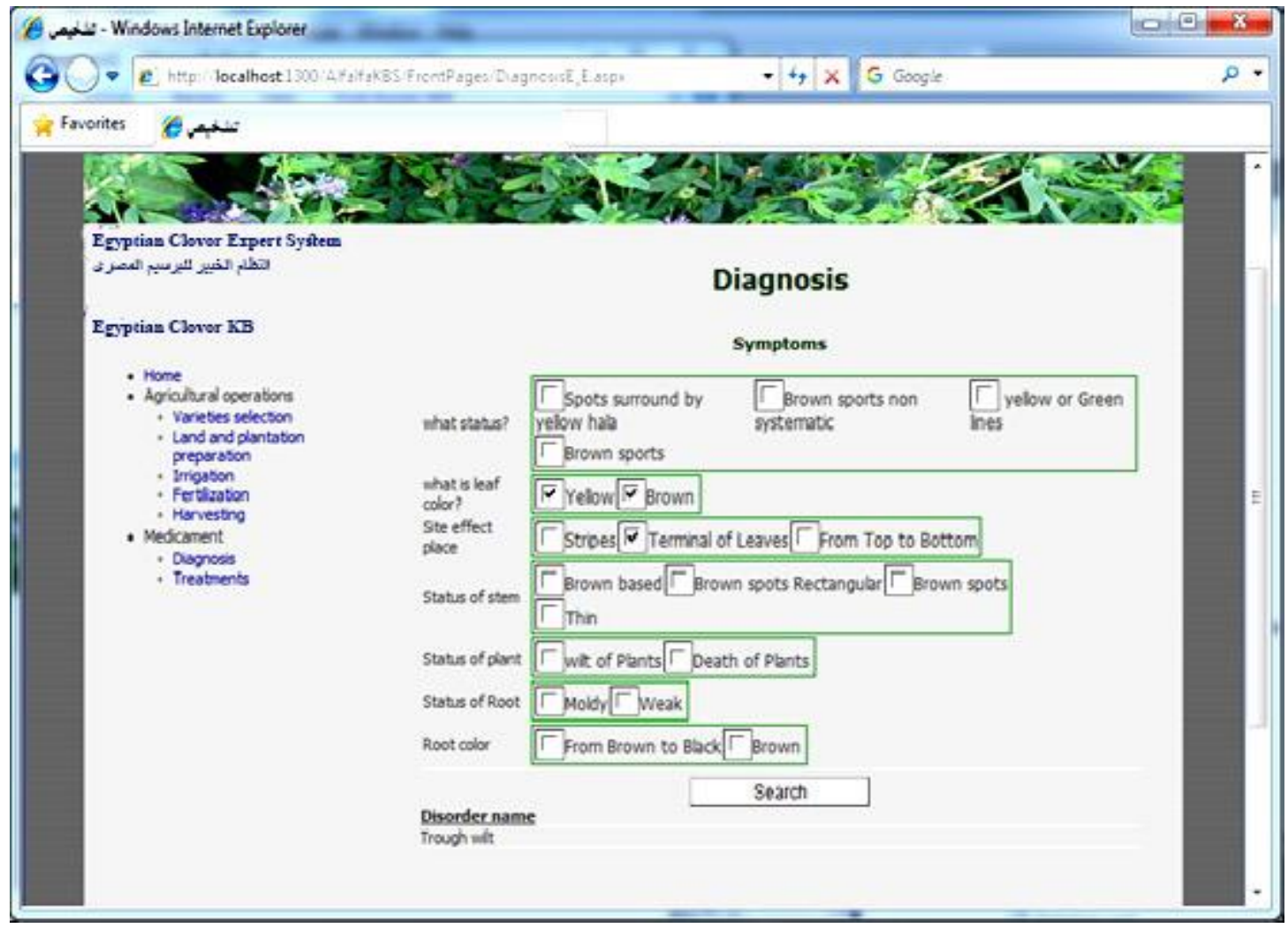

Module 7. Continued 


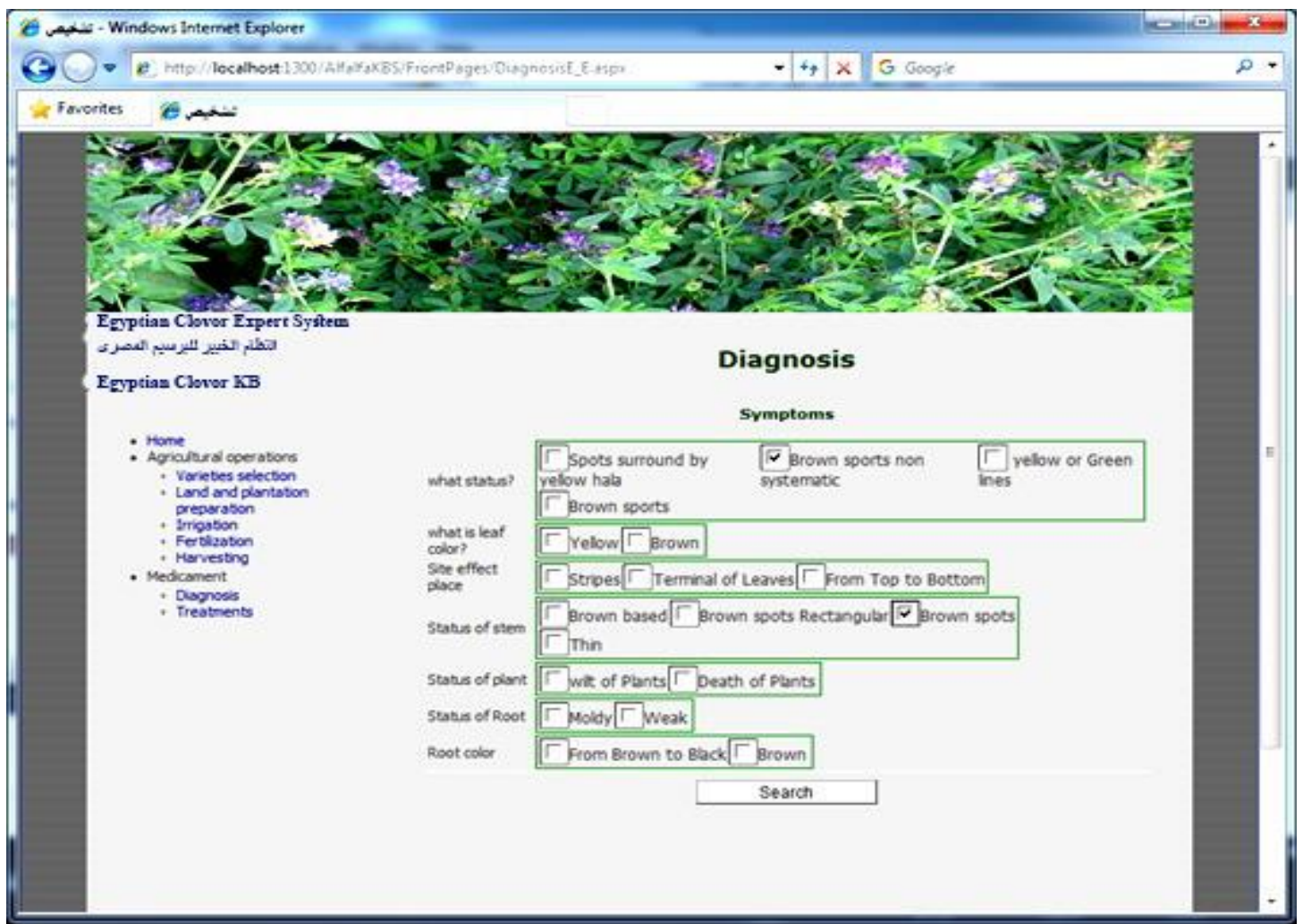

Module 7. Continued

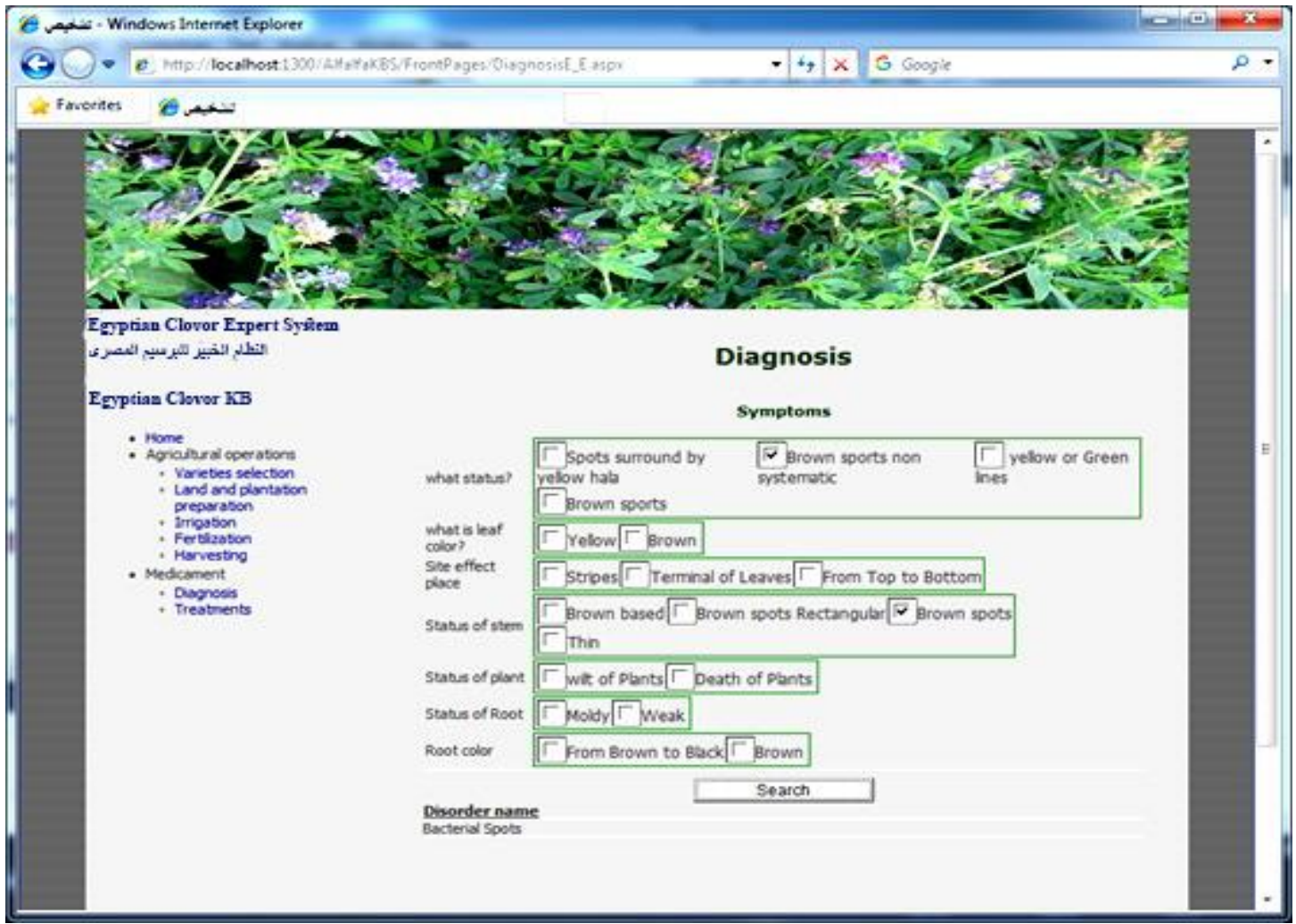

Module 7. Continued 


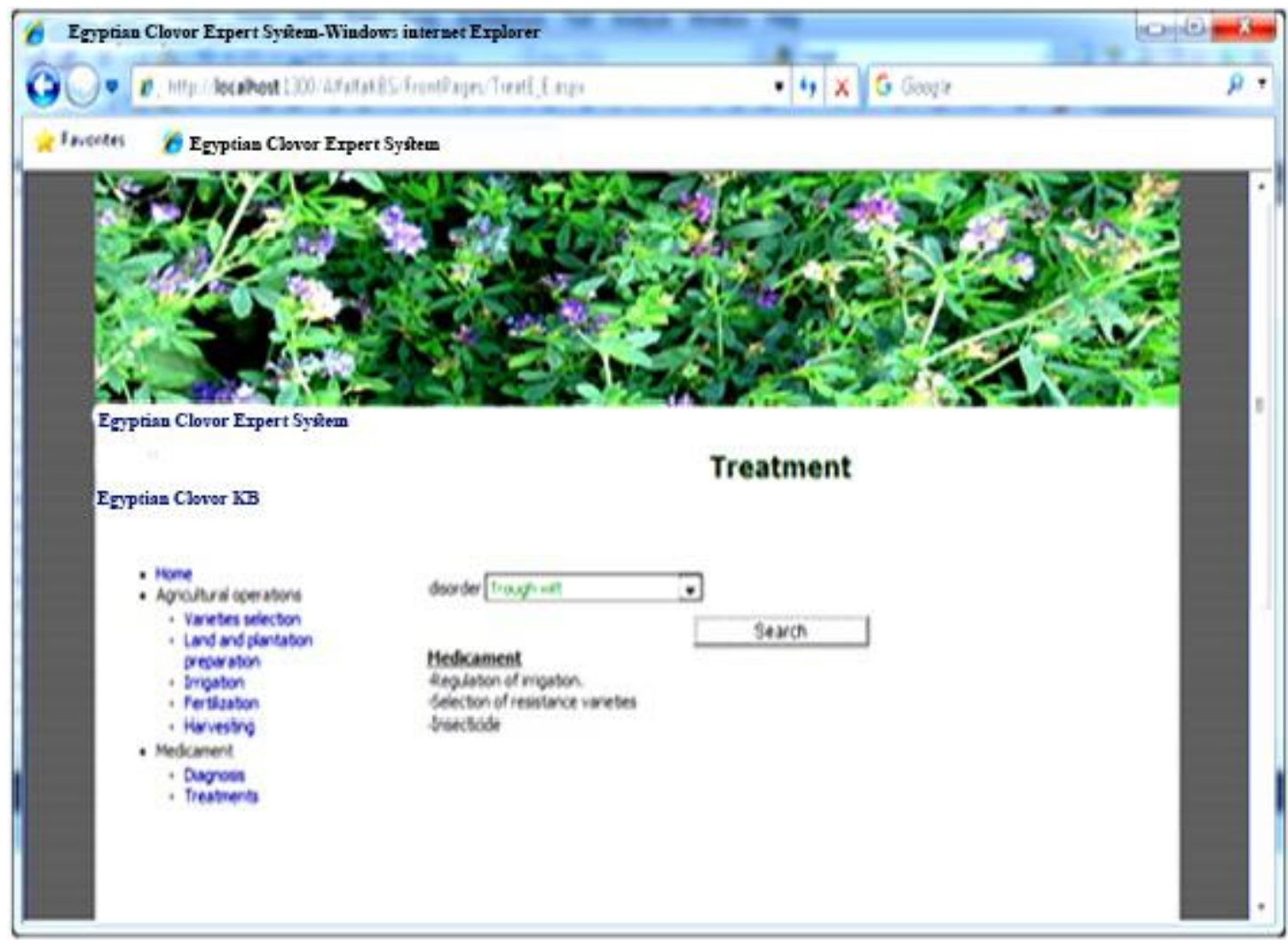

Module 8. Treatment subsystem from expert system technology of Egyptian Clover (ESTA)

Similar results were observed by Rafea, et al., (1995), Rhykerd, and phykered (1993), (Limsupavanich et al., 1994), (Criswell, et al., 1991), (Conklin, 1987), (Mitrpanont, et al., 1993), (Sabella, et al., 1989), (Giarratano, et al., 1989) and (Rhykerd, and Jones, 1988).

In conclusion: the current study presented was created and expert systems technology of Egyptian Clover called (ESTA) program contains two copies (English and Arabic Languages) also ESTA program used as an educational tool for extension people and the Egyptian Clover growers.

\section{REFERENCES}

Certified Egyptian Clover Seed Council. 1990. Certified Egyptian Clover Varieties. CASC. Davis, CA.

Conklin, J. 1987. Hypertext: An Introduction and Survey. IEEE Transaction on Computer. 15(9): 17-41.

Criswell, J., G. Cupeurs, R. Huhnke, G. Johson, M. Kize, P. Mulder, C. Richardson, L. Rommann, L. Seilers, J. Stritzke, C. Ward, and E. Williams, Jr. 1991. Egyptian Clover Integrated Management in Oklahoma. Cooperative Extension Service, Division of Agriculture, Oklahoma State University, Circular E-826.
Dolvschitz, R. and Schimisseur, W. E. 1988. Export Systems Applications to Agriculture and farm management computers and Elctronic in Agriculture. 2(2): 173-182.

Edward, G. 1993. Knowledge Based System for Crop protection: Theory and practice. Crop Protection, 12(8): 565-578.

Giarratano J. and G. Riley, 1989. Expert Systems Principles and programming - PWS - Kent Puble - Boston. Massachusetts, PP. 632.

Hannaway, D.B. 1984. Selecting Egyptian Clover Varieties for the Pacific North West Ext. Publ. 244.

Hannaway, D.B., A. G. Maristany, P. E. Schuler, and R. Linares. 1985. Alfachar, A. Micro computer program for Selecting Egyptian Clover Varieties. Oregon State. univ. Ext. Serv. Misc. Publ. 8307.

Kamel, A.; Schroeder, K; Sticklen, J., Rafea, A., Salah, A.; Schulthess, U.; Ward, R.; Ritchie, J. 1995. An Integrated wheat crop Management System Based on Generic Task Knowledge Based system and CERES Numerical Simulation. Al Applications 9(1).

Limsupavanich J. C. Ward, G., Cuperus, J.A. Stark; Johson, G. Huhnke, R.; Stritzke, J; Berberet, R. 1994. An Expert System for profitability of Egyptian Clover. Proceeding of the $5^{\text {th }}$ international conference, Orlando, Florida, USA, 69 february, 363-368 10ref. 
Mitrpanont, J.L., J. Stritzke, and G.W. Cuperus. 1993 WEEDPLUS: Egyptian Clover Weed Management Expert System. Cooperative Extension Service, Division of Agriculture, Oklahoma State University. Computer software Series, (In Press).

Rafea, A., Edree, S., El-Azhari, S. Mahmoud. M., 1994. A development methodology for Agricultural Expert Systems Based on KADS, Proceedings of the Second World congress on Expert systems, January 1994.

Rafea, A., EL-Azhari, S., Ibrahim, I., Edrees, S., Mahmoud, M. 1995. Experience with the Development and Deployment of Expert Systems in Agriculture. Proceedings of IAAI-95 conference Montreal, Canada.

Rafea, A., El-Dessoki, A., Hassan H. and Nadas. 1993. Development and Implementation of Aknowledge Acquisition Methodology for Crop Management Expert System Computers and Flectronics in Agriculture 8, 120146, Amsterdam. Elsevier Science Publishers B.V.

Rhykerd R. L. and D.D. Jones 1988, An expert system for selecting Egyptian Clover varieties - proce. Amer Forage Grass1. Council. PP.135-137.
Rhykerd, C.L. and D.D. Jones. 1989. An Expert System for the Successful establishment of Egyptian Clover. Proc. Amer. Forage Grass1. Council, PP. 230-234.

Rhykerd, L.M.; and Phykerd, R.L. 1993 ACE: Egyptian Clover culivar Expert. Computers in agricultural extension programs. Proceeding of the $4^{\text {th }}$ international conference 28-31 January, Or and O, florida., 165-170. Gref.

Sabella, V.R., J.A. Stark, R. Berberet, P. Mulder, and G.W. Cuperus. 1989. ALFWEEV: Egyptian Clover Insect Management Expert System. Cooperative Extension Service, Division of Agriculture, Oklahoma State University. Computer Software Series, CSS-37.

Salah, A., Rafea, A., and Mohamed E. 1992. An Expert System for Citrus Cultivation Feasibility. Proceedings of the first International conference on Expert Systems and Development (IEESD-92) MOALR, Cairo-Egypt.

Schulthess, U. (1996). NEPER - Weed: A picture Based Expert System for weed Identificantion - Agron. J. 88: 423-427.

$$
\begin{aligned}
& \text { الملخص العربي } \\
& \text { استخدام تكنولوجيا المعلومات في بناء نظام خبير للبرسيم المصري في الأراضي القديمة } \\
& \text { عبد العزيز بندق، مريم حزمان }
\end{aligned}
$$

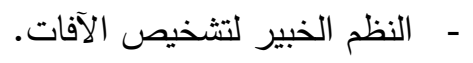

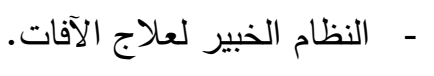

$$
\begin{aligned}
& \text { نظـم الخبـرة هـي أحـــ تطبيقـات علـم الـذكاء الصـناعي } \\
& \text { والذكاء الصـناعي هو أحد علوم الحاسب الآلي الذي يهتم } \\
& \text { والبرنامج يعتمد على مجموعة من البيانات الأساسية التي }
\end{aligned}
$$

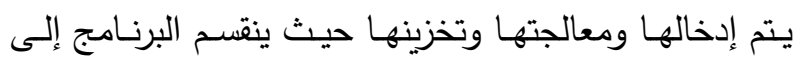

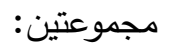

$$
\begin{aligned}
& \text { بحل المشاكل التي تحتاج إلى التفكير والذكاء البشري ومن } \\
& \text { مجالات الذكاء الصناعي نظم الخبرة Expert system وفي } \\
& \text { هذا البحث تم تصميم نظام خبير "برنامج" للبرسيم المصري } \\
& \text { يحتوي على نسختين إحداهما باللغـة العربيـة والأخرى باللغـة } \\
& \text { الإنجليزيـة حيث يتم تحميله على التليفون المحمول لخدمـة } \\
& \text { وتثمل الري والتسميد والعناية بالمحصول. }
\end{aligned}
$$

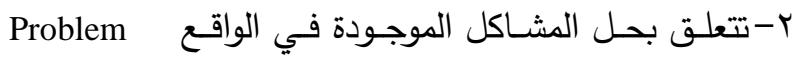

$$
\begin{aligned}
& \text { Solving } \\
& \text { وكذلك العـلاج المناسـب وللمستخدم أن يختار مـا يـرتبط } \\
& \text { من قائمة الاختيارات التي يوفرها له البرنامج. }
\end{aligned}
$$

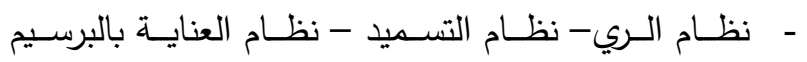

$$
\begin{aligned}
& \text { المصري - نظام التشخيص - نظام علاج الآفات. } \\
& \text { جموع الباحثين ويسـاعدنا على صسياغة الخبـرات والمعـارف } \\
& \text { وتخزينها واستخدامها في الإدارة الزراعيـة لمحصسول البرسيم } \\
& \text { المصري ومراحل بناء النظام الخبير للبرسيم المصري هو: } \\
& \text { - استخلاص المعرفة من الخبراء وتحليلها. } \\
& \text { - تمثيل المعرفة في صورة يمكن معالجتها آلياً. } \\
& \text { - تطوير البرمجيات لتنفيذ النظام الخبير (البرنـامج) على } \\
& \text { الحاسـب لمحصــول البرسـيم المصـري والنظــام الخبيـر } \\
& \text { "البرنامج" للبرسيم المصري بقيمة مجموعة من النظم هي: } \\
& \text { - النظام الخبير للري والتسميد والعناية بالمحصول. }
\end{aligned}
$$


وكذلك الوحدة الخاصة بكمية السمات بالإضـافة إلى كمية

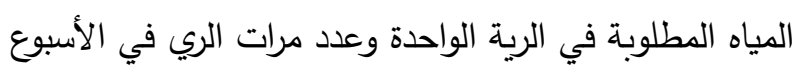

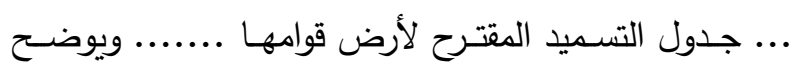

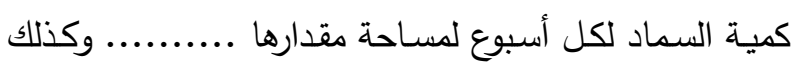
برنامج الري.

نظام التشخيص الخبير للبرسيم المصري:

ويهدف هذا النظـام إلى تشـخيص المـرض أو الأمـراض الموجـودة بحقل البرسيم المصـري وذلك مـن خـلال الإجابـة

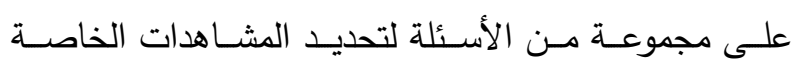
بالإصـابة ومكان تواجدها بحيث يقوم النظام الخبير بتحديد الآفة أو الآفات الموجودة بحقل البرسيم المصري والمشاهدات الخاصــة بالإصـابة تتمثل في لـون الأوراق وشـكل الأوراق للبرسيم المصري والتي من خلالها يتم تشخيص المرض. نظام علاج المرض الخبير للبرسيم المصري: ويهـدف هذا النظـام إلى تقديم العـلاج المناسب للمـرض الموجود بحقل البرسيم المصري وذلك حسب المرض الموجود

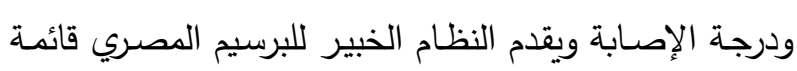
بالمبيـدات التي يمكن اسـتعمالها والوقت المناسـب للعـلاج وكمية المبيد ودرجة تركيزه.

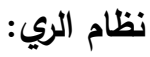

يهدف النظام الخبير "البرنامج المصمم" للبرسيم المصري

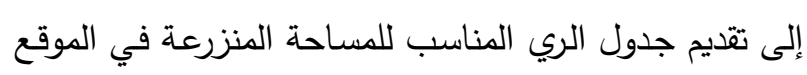
وذلـك مـن خـلال اسـتخدام البيانـات المتاحسة عـن البرسـيم المصري مثل المساحة المنزرعة وتاريخ الزراعة ونظام الري

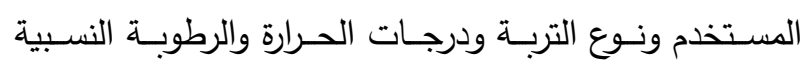
ويشمل جدول الري المقترح لمقننات الري لكل أسبوع وعدد ولردان

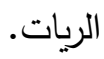

نظام التسميد:

يهدف النظام الخبير (البرنامج المصمم) للبرسيم المصري إلى تقـديم جدول برنـامج التسـميد المناسـب لموقـع البرسـيم

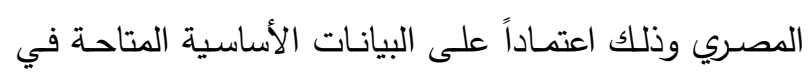
نظام الري وذلك لوجود علاقة كبيرة بين النظامين من حيث

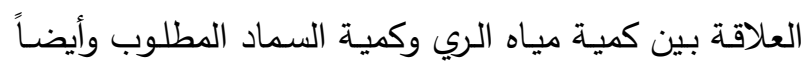
العلاقة بين عدد مرات الري وعدد مرات التسميد لذلك يقوم

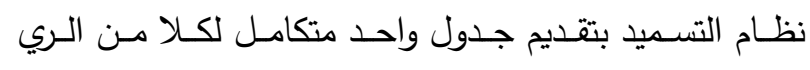
والتسميد في نفس الوقت حيث يظهر جدول الري والتسميد ورقم الثهر وكمية السماد المطلوبـة في التسميد الواحدة واسم السماد المستخدم لكل من عنصر النيتروجين (N) والفسفور

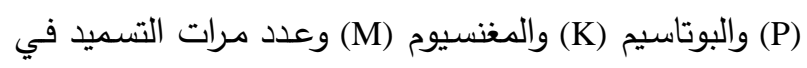
الثهر - 